\title{
The Development of Caring Thinking Skills Inventory Based on Problem Scenarios: A Study of Validation and Reliability
}

\author{
Ufuk Uluçınar ${ }^{1, *}$, Asım Arı ${ }^{2}$ \\ ${ }^{1}$ Division of Curriculum and Instruction, Faculty of Education, Uşak University, Turkey \\ ${ }^{2}$ Division of Curriculum and Instruction, Eskişehir Osmangazi University, Turkey
}

Copyright $\bigcirc 2019$ by authors, all rights reserved. Authors agree that this article remains permanently open access under the terms of the Creative Commons Attribution License 4.0 International License

\begin{abstract}
Caring thinking as a higher order thinking type has both cognitive and affective components, as Lipman stated. Attributed as thinking depending on affects, emotion, the heart, beliefs, it is associated with the processes of Krathwohl's affective domain taxonomy. In this study, therefore, it was aimed to develop an inventory of caring thinking skills towards middle school students, which was designed by and grounded on Krathwohl's taxonomy. For the inventory, the processes of sequential exploratory mixed design were employed in this study. The caring thinking skills inventory accounts for 20 problem scenarios, which have 5 options, and 100 items. The lowest point is 20 , and the highest point is 100 . Giving an answer is quite easy. The degree to what students think caringly can be measured using an answer key which rating of items ranging from 1 to 5 in each scenario. The inventory designed and developed to understand if caring thinking is a measurable and improvable skill and whether it is valid and reliable data collection instrument as a result of respectively, qualitative and quantitative studies performed. It is recommended that the inventory should be used in measuring students' affective behaviors, dispositions, and skills toward real world experiences.
\end{abstract}

Keywords Caring Thinking, Inventory, Affective Domain in Taxonomy, Higher Order Thinking

\section{Introduction}

Generally, all the societies aim to educate individuals who think. They meet societal needs regarding both their own self - control and responsibilities. From the past to present, educators have tried to explain the concept 'thought' by means of 'mind' and 'sense' via informal or formal curricula. Splitter pointed out an assumption that teaching to learn better means thinking better as an ideal [1]. In that case, teaching 'thought on thinking' [2] an advanced thinking type is an educational ideal in terms of own learning of the individual and societal necessities. Therefore, higher order thinking skills can be seen as an ideal method for what a thinking type is.

Based on historical and conceptual analysis of higher order thinking skills like critical thinking, problem solving, decision making, and creative thinking, it's roles on education, and significance in curricula, and efficiency have been discussed (Streib, 1991). As it will be understood, these skills represent abilities greatly based on cognitive fundamentals. That is, we employ logical rules, criteria, standards, reasons, and methods suitable to our thoughts in critical thinking. We also discover novel ways to express ourselves, and the environment; we try to reveal beyond unseen innovations before employing creative thinking [3]. Furthermore, we use hypothesis, credible and reliable sources, scientific research methods, assumptions, possible best appropriate solutions in problem solving. However, the affective dimension of these skills has been undermined in education. Sharp pointed out that emotions need to be incorporated into the inquiry community based these skills [4]. While we employ them in using the right to choose, and making a decision, these choices, and decisions have an impact on our judgments. Therefore, the role of emotions indeed, stands for our thoughts which help to reach our judgments [3]. In this respect, it has been emphasized that individuals need to think with their emotions, that is, thinking caringly while they think critically and creatively. Thusly, a higher order thinking occurred without caring is devoid of the element of values.

The number of study on caring thinking is extremely limited. A part of them is review; some are on document analysis. For example, Fard, Nasrabadi \& Heidari scrutinized the stories in Masnavi according to Lipman's views of philosophical thought. They searched the statue of 
critical, creative, and caring thinking skills in them. Caring thinking skills are encountered as well as critical and creative thinking. In all the three stories, normative thinking is identified. Appreciative and emphatic thinking are absent in all the stories. The authors argued that the stories include normative thinking, and that have a crucial impact on strengthening students' caring thinking [4]. Similarly, in a study of Shaari \& Hamzah (2018) on document analysis, they compared Lipman's thinking, and Islamic cognitive processes models in terms of cognitive principles, the dimensions of caring thinking, thinking logic, the structure of human being, and roles. Appreciative thinking is associated with thankfulness (syukr); affective thinking explains the ability to and control emotions, and temper as stated in love (mahabbah), and patience (sabr) in Islamic perspective. Active thinking includes action decisions taken to act as related to hope (raja), and fear (khawf) concepts. According to them, Islam encourages normative thinking since it set forth reflection/self-regulation, and repentance (tawbah). Emphatic thinking corresponds to "poor" process in counterpart model (faqr). The thinking logic of Lipman model focuses on just 'human development for human' while Mohd Daud Hamzah and Abdul Kadir Arifin' model deals with more scale discourse. As for the structure of human being, Lipman model emphasizes both mental, and emotional balance, other hand, the model of Islamic perspective suggest that human character is more holistic. Caring thinking in Islam comprises the external and internal characteristics of self-transformation, and renovation [5].

Dombayci suggested that the content and methods about how the environmental ethics can be taught through caring thinking. He stated also that classroom community of inquiry can affect the development of caring thinking. Dombayci, set forth three books to be used in contexts where caring thinking can be stimulated. These books titled 'The Giving Tree, The Lorax and The Little House' contain the examples of environment ethics. He argues that the environment ethics can be taught by means of focus questions, and processes incentive caring thinking. By him, the instructional process will contribute to understand the principles of sustainable living via caring thinking. It can be possible to build a sustainable society, show respect, and care for the community of life, improve the quality of human life, preserve vitality, and variety of the Earth, change personal attitude, and practices, be careful toward community own environments, and create global value based partnerships via caring thinking [6].

Sharp focused greatly on the development of emotions in caring thinking. If someone wants to make students good judgments, he or she must educate their emotions. Because, caring thinking encourages thinking, and emotions. Meanwhile, caring thinking aims to reinforce causal awareness, dialog, understanding, and inquiry as well as it promotes to students think the reasonableness of emotions in given context. Therefore, she emphasizes the education of emotions via classroom philosophy of inquiry. Transforming the traditional classrooms into inquiry community helps not only students think more; but also the development in emotional maturity. The community strengthens the development of critical, creative, and caring thinking. A classroom community of inquiry should provide students with the following opportunities, as well as critical, and creative thinking: (1) identifying own emotions, (2) helping students reveal the underlying belief of emotions, (3) helping them the way to understand, and identify their emotions, (4) helping them get rid of the emotions that they could make no sense for themselves [7].

Having done an empirical study of teaching caring thinking, Lee \& Chung, aims to promote children' caring thinking through philosophical community of inquiry. A 12 weeks' inquiry research were conducted to understand how caring thinking can be revealed in this community, and all the processes were recorded. 5 dimensions, and 38 characteristics of caring thinking were observed in the community of inquiry. With increase in the number of such activities, the amount of concepts associated with caring thinking ascended. As caring thinking changed, the direction of discussion flew the teacher-student to student-student interaction. It helped to improve caring thinking skills [8].

Caring thinking has been taught in 'Philosophy for Children' as well as critical and creative thinking in order to acquire students' philosophical attitude and higher order thinking skills in 46 countries. Similarly, in Turkey, The Ministry of National Education prepared 'the thinking skills' curriculum which aims to teach students to think accurately for 6-8 graders. The focus of this curriculum is ground on the teaching critical, creative, and caring thinking skills based on 'Philosophy for Children' program. With a general expression, it aims to cultivate the individuals who think on own thought, recognize the ways of their own thinking, show the respect for other thoughts, use an accurate and caring language in interaction with the people, and have an accumulation of knowledge and culture of discussion [9]. However, caring thinking as a higher order thinking skill has been still not included in interdisciplinary curricula just as critical and creative thinking in the context of Turkey. Nonetheless, this situation is an issue of another study. Since the caring thinking skills have been addressed at first in this curriculum, the audience of this inventory is middle school students. The data were obtained from 7 th grade (14 years old in average) students.

Although Lipman defined conceptually caring thinking as a combination of critical thinking and creative thinking, he did not present neither theoretical nor empirical evidence about the role of critical thinking on the process of caring thinking [10]. The inter-associations of higher order thinking skills like critical thinking, problem solving, creative thinking, and reflective thinking have been 
discovered, and interpreted. For example, an analysis, and interpretation made about how to and where use problem solving skills in thinking critically is a significant finding. It is possible to say that such an association contributes to educators teach effectively them. In addition, these questions need to be inquired in order to facilitate to perform multidimensional thinking education in the school: which higher order thinking skills do have an effect on decision making? Which thinking skill is priority than others and which thinking skills do work simultaneously? [10]. Streib answered these questions in his doctorate thesis entitled 'the history and analysis of critical thinking', and revealed clearly interconnections of higher order thinking skills. Another way to explain the relationships but theoretical scrutinization is empirical results as mentioned previously. However, the fact that the absent of any data collection instrument measuring caring thinking make it no possible statistically the testing of the interconnections of caring thinking and other higher thinking skills. Therefore, this study aims to contribute to solve theoretical and practical problems by developing a data collection instrument measuring caring thinking skills in the literature.

Beyond the definition, and dimensional characteristics of caring thinking that Lipman conceptualized [2], there is little information, and explanations about what the connections between caring thinking and affective structures are. It is obscure which he/ she employs affective structures while an individual thinks caringly. Caring thinking relies on affective components like curiosity, love, scary, trust, hate, values, beliefs, preferences, concern, attitudes, and motivation. In this context, the issue of another is to determine how caring thinking is associated with the characteristics expressed above. It has been thought that it will help to teach them efficiently, and in proper in affective behavior education. Krathwohl, Bloom \& Masia developed affective domain taxonomy which helps to teach students values, emotions, beliefs, attitudes etc. and it has systematic and hierarchical multistage framework consisting sequentially receiving, responding, valuing, organization, and characterization [11]. In this study, we ground on these processes designing caring thinking skills inventory. By courtesy of the inventory, we can measure the degree to affective behaviors and dispositions the individuals have displayed against real world problems as well as caring thinking.

Furthermore, it is seen that many scales, interviews, tests, or inventories are present when we have searched the literature on the data collection tools measuring higher order thinking skills. For example, The California Critical Thinking Skills Test, The California Critical Thinking Dispositions Inventory, Cornell Critical Thinking Test, Critical Thinking Interview, and The Ennis-Weir Critical Thinking Essay Test on critical thinking were developed by many theorists, which has universal prominent usage [12]. There are also pretty instruments on creative thinking: The
Creativity Assessment Packet by Frank Williams, (1980, 1993), The Williams Scale, Exercise in Divergent Thinking (Form A, and B), Torrance Tests of Creative Thinking (Verbal Form A- Figural Form A), PYTHAGORAS: Form B/C, Experimental Measures of Verbal and Nonverbal Creativity by Greg A. Grove (1999), The Wechsler Abbreviated Scale of Intelligence (WASI) by David Wechsler (1999), The Luscher Color Test by Max Luscher, (1948, 1969), and The Preconscious Activity Scale by John L. Holland, and Leonard L. Baird (1968). Moreover, for reflective thinking, a Reflective Thinking Open-Ended Questionnaire and Interview Questionnaire by Mirzaei, Phang \& Kashefi [13], The Rubric for Evaluating Portfolio Reflective Thinking instrument by Pennington [14], and a Questionnaire of Assessing Reflective Thinking in Solving Design Problems (ARTiD) by Hong and Choi [15], and Reflective Teaching Observation Instrument by Jadallah [16] were developed.

Beyond the definitions of caring thinking as one of the higher order thinking skills, the need of empirical studies on the contributions of caring thinking as explained above has been uttered. Therefore, to develop the caring thinking skills inventory for middle school students may be a helpful device to solve on these issues.

\subsection{Caring Thinking}

Caring thinking is an affective education approach conceptualized firstly by Matthew Lipman who was founder for the Philosophy for Children in USA [17]. He defined that caring thinking represents a formula that combines critical and creative thinking [3]. It includes the forms leading to emotions transform to the choices, decisions, and judgments. These forms stand for structures helping to people think caringly toward self, others, the environment, and the principles [18]. It refers to the type of thinking with the heart, namely, thinking with emotions. Sharp defined caring thinking as a combination of affective and cognitive processes [7]. With a general expression, it was explained as thinking based on the individual's own values. It helps to students develop a powerful values system to make rigor, passionate decisions. It also consists of valuing other people, respecting for them, compassion, improvement, consolation, concerning about them, raising, showing an emphatic, sympathy, appreciation, and celebration.

\subsubsection{Appreciative Thinking}

This type of caring thinking is called as appreciative thinking since it refers to thinking based on the facts, or objects, and the human that the individual gives an importance, values, and appreciates. That the person appreciates any object or the other people needs to be interested in them, being a significant for them, or making any sense for self-respect. Appreciative thinking also concerns with the extent to what caring to what the person 
makes any sense. Valuing any object or the person means appreciating, or prizing it. It has two dimensions. First dimension is valuing tangible objects sensual and esthetics appeal rather than monetary values. In other words, it is valuing the nature, art, or objects of which the value and beauty are seen clearly. Another dimension of caring thinking is that people value abstract facts like attitude, behavior, or personal characteristics. Furthermore, a feature of this thinking type is that it relies on ethics and moral principles [7].

\subsubsection{Affective Thinking}

Affective thinking refers the affective and cognitive response to controversial issues. In other words, it is the reaction that the individuals display against the feelings revealed about facts, and events that they value or appreciate. Affective thinking is an effective response that an individual, who has a clear understanding or a powerful justice sense about what is right and what is wrong, gives against making a fault. Fundamental regulative ideas and actions are as follows: Moral, feeling the fault, ethics, evaluation, judgment, norms, responding, unethical behavior, unmoral behavior, making it proper, and feeling the right.

\subsubsection{Active Thinking}

Active thinking is regarded as the state of acting toward what we value or care about. It also cares about passionately toward a situation based on a reason. The thinking type needs to use a language, prepare a plan, and act it toward a reason or thought. The concepts and processes of active thinking are improvement, acting, development, formation, protection, conservation, cultivation, sustain, and taking precautions.

\subsubsection{Normative Thinking}

Normative thinking is a skill type of caring thinking that it can be performed in the local or global contexts. Students usually are concerned with universal law, principles, global issues like the protecting environment, animal, and human rights. Empathy, moral imaginative power, and avoiding egocentric thinking appear in normative thinking. The sensitive to discrepancies between ideals and current situations, conceptualizing issues that society undergo, and coming up with the solutions, and dealing with in-depth human and global challenges are the fundamentals of normative thinking [7]. It also involves actions like predicting, generalizing, criticizing, improving, creating a plan, reflecting, considering the possibilities, designing, and seeking better one.

\subsubsection{Empathic Thinking}

The term 'empathy' has varied meanings, but according to Lipman [2], it was defined as 'feeling, thinking, or behaving as if we had experienced the event, situation, or challenge the others did.' That is, a way to taking care of the others is to think if we had their emotions, perspectives, or thoughts eluding own our emotions, and perspectives.

\section{Design}

\subsection{The Research Model}

Aiming to develop an inventory of caring thinking skills towards middle school students, the processes of sequential exploratory mixed design were employed in this study. The researcher utilizes firstly qualitative findings (exploratory) to develop an instrument or a theory, and then tests the validity and reliability of the instrument that he/she has designed based on these qualitative results in quantitative phase $[19,20]$. In this context, the processes employed in qualitative and quantitative steps are as follows:

\subsubsection{Constructing Problem Scenarios}

Problem scenarios were prepared suitably to the attainments of an affective-based curriculum. In this respect, 20 problem scenarios which meet 20 objectives or attainments (Appendix A) were written. Moreover, they were constructed in that way compass four each scenario for appreciative thinking, affective thinking, active thinking, normative thinking, and emphatic thinking. While constructing them, we applied the opinions of an expert on test development in order to assess the general structure of the inventory, and an expert on Turkish language to determine the appropriateness of scenarios prepared - developmental stages of middle school students. In order that the inventory developed can be applied to students validly, and effectively, scenarios need to be considered issues such as (a) students' development stage, and interests, (b) themes, (c) subject, and (d) content conformity [21, 22]. Since scenarios consist of paragraphs changing three-five rows, we also took the views of an expert on reading skills in order to strengthen the structure validity of the inventory against the possibility of measuring only reading skills of students.

\subsubsection{Assessing the Content Validity of the Appropriateness of Scenarios - Attainments}

We applied the opinions of experts in order to assess the scenarios written in terms of grammar and manner of telling, relevance of scenario - attainment, and intelligibility.

\subsection{A Scenario Example}

Emrah, who is son of a rich family decides to be a teacher and left from the management of father's company. Whereas his mother and father's insistences, Emrah comes as a teacher to Gürlek village situated in Banaz town, Uşak province. He encounters Salih with his worn out clothes in 
a village road looking alike a muddy footpath. Salih is a son of family, whose mother deals with chores, and father runs coffeehouse of the village. Emrah stating first 'Hello 'to Salih, said that "My name is Emrah, and I have been appointed here as teacher. What's your name?" from tiny and frail boy, it calls Salih as the reply to him with a hoarse sound". When Salih hears that Emrah is a teacher, his eyes shine. He asked that "are you really a teacher? Emrah said that yes, I am a teacher, can you take me the village? Salih, standing up with an enterprise manner proceed together with the teacher to the village. The teacher says that what's this, Salih? Showing a home in ruins at the entrance of the village. Salih says it was our village's school, and could not been used for long time since a teacher has not come here, therefore, it stood still. So, we cannot go to the school." The teacher is shocked after this response reaches the old school. He sees a worse scene when he enters the school. Desks are broken, mice strolling around them. The teacher Emrah was different ideals coming to the village, and he has disappointed, now.

\begin{tabular}{|l|l|l|l|l|l|}
\hline Attainment & \multicolumn{4}{|l|}{ Students will be tidy both themselves, and the environment in case of mess considering their current principles. } \\
\hline & Not at all & Little & Moderately & Extremely & Quitely \\
\hline Appropriateness & {$[1]$} & {$[2]$} & {$[3]$} & {$[4]$} & {$[5]$} \\
\hline Intelligibility & {$[1]$} & {$[2]$} & {$[3]$} & {$[4]$} & {$[5]$} \\
\hline
\end{tabular}

For each scenario, experts were asked to assess (a) impaired expression, (b) written error, (c) appropriateness of scenarios - attainments, and (d) intelligibility of scenarios. Demographical data of experts participated in this phase of the study is in Table 1.

Table 1. Demographical data of the experts participated in the study of content validity of Compatibility of scenarios - attainment

\begin{tabular}{|c|c|c|c|}
\hline Code name & Tittle & Expertise area & Years of work experience \\
\hline C.T. & Assoc. Prof. & Science education & 16 \\
\hline Z.B. & Assoc. Prof. & Turkish language education & 15 \\
\hline Y.A. & Assist Prof. & Curriculum and instruction & 7 \\
\hline E.K. & Assist Prof. & Science education & 12 \\
\hline Y.T.D. & Assist Prof. & Curriculum and instruction & 8 \\
\hline
\end{tabular}

Five experts took part in for content validity of compatibility of scenarios - attainments. Their domains of expertise vary in several disciplines such as science education, Turkish language education, curriculum and instruction. 2 of 5 experts are Assoc. Prof., remaining are Assist Prof. 


\subsubsection{Obtaining Students' Written Statements on the Scenarios}

The data were obtained from students for the writing items. They were asked to read each scenario, and express their opinions of situation in the scenarios following the possibilities. The sample of data collection form created in the booklet format is below.

Emrah, who is son of a rich family decides to be a teacher and left from the management of father's company. Whereas his mother and father's insistences, Emrah comes as a teacher to Gürlek village situated in Banaz town, Uşak province. He encounters Salih with his worn out clothes in a village road looking alike a muddy footpath. Salih is a son of family, whose mother deals with chores, and father runs coffeehouse of the village. Emrah stating first 'Hello "to Salih, said that "My name is Emrah, and I have been appointed here as teacher. What's your name?" from tiny, and frail boy, it calls Salih as the reply to him with a hoarse sound". When Salih hears that Emrah is a teacher, his eyes shine. He asked that "are you really a teacher? Emrah said that yes, I am a teacher, can you take me the village? Salih, standing up with an enterprise manner proceed together with the teacher to the village. The teacher says that what's this, Salih? showing a home in ruins at the entrance of the village. Salih says it was our village's school, and could not been used for long time since a teacher has not come here, therefore, it stood still. So, we cannot go to the school." The teacher shocked after this response reaches the old school. He sees a worse scene when he enters the school. Desks are broken, mice strolling around them. The teacher Emrah was different ideals coming to the village, and he has disappointed, now.

TIP. You have two possibilities. Firstly, let read Possibility 1. If this option is suitable for you, you can mark it. If it is not, you should answer the question in few sentences in Possibility 2.

\begin{tabular}{|l|l|l|}
\hline Possibility 1 & $\begin{array}{l}\text { If you think teacher Emrah will go back due to bad conditions, you can mark } \\
\text { the right box. }\end{array}$ & [ ] \\
\hline Possibility 2 & $\begin{array}{l}\text { What ideals may teacher Emrah come to the village regarding school environment? If you were teacher } \\
\text { Emrah, what would you do to regulate the school? Please, write this reason. }\end{array}$ \\
\hline
\end{tabular}

Note for students. After you make your interpretations about scenarios above, please do not regulation again. Let proceed next one.

We applied to students' views to write items of scenarios of caring thinking skills inventory. 54 middle school students were randomly chosen from a school at a medium layer socioeconomically. Demographical information of students is presented in Table 2.

Table 2. Demographical information of students whose responses were applied for writing items of scenarios in caring thinking skills inventory

\begin{tabular}{|l|l|l|l|l|l|}
\hline & 1 & 2 & 3 & 4 & Total \\
\hline Gender & Female & Male & & & \\
\hline $\mathrm{N}$ & 26 & 28 & & & 54 \\
\hline$\%$ & 48,1 & 51,9 & & & 100 \\
\hline Mother edu. statue & Elem. & Middle & High school & Uni. & \\
\hline $\mathrm{N}$ & 14 & 20 & 14 & 6 & 54 \\
\hline$\%$ & 25,9 & 37 & 25,9 & 1,1 & 100 \\
\hline Father edu. statue & Elem. & Middle & High school & Uni. & \\
\hline $\mathrm{N}$ & 6 & 12 & 25 & 11 & 54 \\
\hline$\%$ & 1,1 & 22,2 & 46,2 & 20,4 & 100 \\
\hline
\end{tabular}

Table 2 consists of students' demographical information such as gender, mother and father educational statues. The percentile of female students is 48,1 those of male is 51,9 . As for the number of mother educational statues, those of elementary are 14; middle school is 20 ; high school is 14 ; university is 6 . Students' father educational statues respectively also are: 6 elementary $(\% 1,1) ; 12$ middle school $(\% 22,2) ; 25$ high school $(\% 46,2)$ and 11 university $(\% 20,4)$. 


\subsubsection{Writing the Items of Scenarios by Stages of Krathwohl Affective Domain Taxonomy}

The caring thinking skills inventory, which was designed basing on affective domain taxonomy by Krathwohl, Bloom, and Masia is grounded on a powerful theory scientifically [11]. After students' responses of scenarios were obtained qualitatively, the items of scenarios have been written. These items were constructed hierarchically in five stage based on affective domain taxonomy of Krathwohl, Bloom, and Masia. These stages are; (a) uncaring thinking, (b) awareness/ meaning (c) valuing, (d) reasoning/ organization, (e) caring thinking or behavior. Written statements or responses from students were classified, and organized.

Problem scenarios were constructed considering the dimensions of appreciative thinking, affective thinking, normative thinking, active thinking, and emphatic thinking of caring thinking. The items of problem scenarios created for each type of caring thinking were written considering five stages mentioned above. A table including stages, descriptive, and pointing of five caring thinking skills were created.

Table 3. The Points, Stages, and Descriptive of Appreciative Thinking Skills

\begin{tabular}{|c|c|c|}
\hline Point & Stage & Descriptive \\
\hline 1 points & $\begin{array}{l}\text { Uncaring } \\
\text { thinking }\end{array}$ & $\begin{array}{l}\text { The individual doesn't have any } \\
\text { feeling, emotion, and thought about } \\
\text { a person, situation, or event } \\
\text { appreciated. He/ she displays } \\
\text { uncaring or insensitive behaviors. }\end{array}$ \\
\hline 2 points & $\begin{array}{l}\text { Recognizing/ } \\
\text { awareness/ } \\
\text { understanding }\end{array}$ & $\begin{array}{l}\text { The person recognize sufficiently } \\
\text { events or people appreciated, he/ she } \\
\text { aware this event with whom, and } \\
\text { what it is related. He/ she can } \\
\text { understand a value appreciated, and } \\
\text { use differentiated skills about it. }\end{array}$ \\
\hline 3 points & Valuing & $\begin{array}{l}\text { The degree of valuing it that the } \\
\text { individual aware deficiently about } \\
\text { events, or situation is a necessary } \\
\text { element increasing caring thinking. } \\
\text { In stage, he/ she is expected to } \\
\text { display behavior or thinking that he/ } \\
\text { she values, and appreciate. }\end{array}$ \\
\hline 4 points & $\begin{array}{l}\text { Reasoning/ } \\
\text { organizing }\end{array}$ & $\begin{array}{l}\text { A reason of importance that the } \\
\text { individual gives, and the valuing } \\
\text { contributes to develop caring } \\
\text { thinking. He/ she can apply critical } \\
\text { and inquiry skills }\end{array}$ \\
\hline 5 points & $\begin{array}{l}\text { Thinking } \\
\text { alternative } \\
\text { possibilities / } \\
\text { caring } \\
\text { thinking }\end{array}$ & $\begin{array}{l}\text { In this stage, the individual searches } \\
\text { alternative, new ways to improve } \\
\text { own values towards the person or } \\
\text { situation appreciated after he/ she } \\
\text { make an assessment regarding the } \\
\text { degree of valuing, and importance, } \\
\text { He/ she uses imagination, and } \\
\text { creative thinking skills. }\end{array}$ \\
\hline
\end{tabular}

\subsubsection{Assessing Compatibility of the Items of Scenarios - the Stages of Taxonomy}

The items of caring thinking skills inventory were suitably written based on the stage of affective domain taxonomy benefiting from students' written expressions. In order to assess whether the items conform or not to the stages, face validity was performed.

Face validity is a type of validation that a researcher reaches an agreement that the instrument really measures fact or concept targeted by examining the items of a questionnaire. The experts assess it if each item meets a given conceptual structure or theme by meaning, and logically [23]. They were expected to assess if the items written meet the criteria determined for each stage by comparing the items in each stage with criteria in same stages. They also were asked to write the ideal item expected to be when the items are not suitable to the stages stated. Furthermore, they were asked to do ratings (1-5) in order to assess the degree of compatibility of the items stages.

Emrah, who is son of a rich family decides to be a teacher and left from the management of father's company. Whereas his mother and father's insistences, Emrah comes as a teacher to Gürlek village situated in Banaz town, Uşak province. He encounters Salih with his worn out clothes in a village road looking alike a muddy footpath. Salih is a son of family, whose mother deals with chores, and father runs coffeehouse of the village. Emrah stating first 'Hello 'to Salih, said that "My name is Emrah, and I have been appointed here as teacher. What's your name?" from tiny, and frail boy, it calls Salih as the reply to him with a hoarse sound". When Salih hears that Emrah is a teacher, his eyes shine. He asked that "are you really a teacher? Emrah said that yes, I am a teacher, can you take me the village? Salih, standing up with an enterprise manner proceed together with the teacher to the village. The teacher says that what's this, Salih? showing a home in ruins at the entrance of the village. Salih says it was our village's school, and could not been used for long time since a teacher has not come here, therefore, it stood still. So, we cannot go to the school." The teacher shocked after this response reaches the old school. He sees a worse scene when he enters the school. Desks are broken, mice strolling around them. The teacher Emrah was different ideals coming to the village, and he has disappointed, now.

Considering scenario above, what do you expect teacher Emrah to do? 


\begin{tabular}{|c|c|c|c|c|c|c|}
\hline \multicolumn{7}{|c|}{ NORMATIVE THINKING } \\
\hline \multicolumn{5}{|c|}{ Compatibility } & \multicolumn{2}{|c|}{ Teacher Emrah } \\
\hline 1 & 2 & 3 & 4 & 5 & 1.stage & He drags one's feet against bad conditions. \\
\hline 1 & 2 & 3 & 4 & 5 & 2. stage & He understands that he needs to highly strive in order to make the school usable. \\
\hline 1 & 2 & 3 & 4 & 5 & 3. stage & The teacher regards current conditions of the school as a worthwhile matter for education and teaching. \\
\hline 1 & 2 & 3 & 4 & 5 & 4. stage & He thinks that children also in the village like others are required to receive training for a good future. \\
\hline 1 & 2 & 3 & 4 & 5 & 5. stage & He searches aid from the state to improve the school considering his own ideals. \\
\hline
\end{tabular}

We applied to the opinions of three experts to perform the face validation. Demographical information of experts took part in this stage of the study were presented below:

Table 4. Demographical data of experts participated in a study of face validation for compatibility of items - taxonomical stages

\begin{tabular}{|c|c|c|c|}
\hline Code name & Title & Expertise area & Seniority \\
\hline S.G.M & Assist Prof. & Instructional technologies & 10 \\
\hline H.B. & Assist Prof. & Psychological Counselling, Guidance & 9 \\
\hline U.B. & Res. Assist. Dr. & Sociology/ Philosophy & 7 \\
\hline
\end{tabular}

Three experts participated in a study of face validation for compatibility of items - taxonomical stages. Their expertise is on Instructional Technologies, Psychological Counselling, Guidance, and Sociology/ Philosophy.

Second phase of exploratory sequential mixed design consists of the implementation of the instrument, calculating lower $\% 27$ - upper $\% 27$ item discrimination to perform structure validation and computing the reliabilities of scenarios.

\subsubsection{Appling the Inventory of Caring Thinking Skills}

The pilot study was carried out in order to perform the construct validity of the inventory of caring thinking skills. Demographical data of whose students participated in pilot study of the instrument was presented as below:

Table 5. Demographical data of whom students participated in pilot study of the instrument

\begin{tabular}{|c|c|c|c|c|c|c|}
\hline & 1 & 2 & 3 & 4 & Missing & Total \\
\hline Gender & Female & Male & & & & \\
\hline $\mathrm{N}$ & 103 & 81 & & & & 184 \\
\hline$\%$ & 56,0 & 44,0 & & & & 100 \\
\hline $\begin{array}{c}\text { Mother education } \\
\text { statue }\end{array}$ & Elem. school & Mid. school & High school & University & & \\
\hline $\mathrm{N}$ & 67 & 54 & 39 & 17 & 7 & 184 \\
\hline$\%$ & 36,4 & 29,3 & 21,2 & 9,2 & 3,8 & 100 \\
\hline Father education statue & Elem. school & Mid. school & High school & University & & 6 \\
\hline $\mathrm{N}$ & 31 & 43 & 72 & 32 & & 184 \\
\hline$\%$ & 16,8 & 23,4 & 39,1 & 17,4 & 3,3 & 100 \\
\hline
\end{tabular}

Table 5 shows that 103 female $(\% 56)$, and 81 male $(\% 44)$ students took part in pilot study of instrument. The elementary school ratio of mother educational statues is 36, then middle school, 29,3; high school, 21,2; university, 9,2. As for the number of father educational statues, respectively, the elementary school 31, middle school 43, high school 72, and university 32 . 


\subsubsection{Calculating Lower $\% 27$ - Upper \%27 Item Discrimination Indices}

The following types of content and face validation were performed respectively; the construct validity was carried out. The lower $\% 27$ - upper $\% 27$ item discrimination analysis, one of the methods of construct validation was executed. The item discrimination indices are a coefficient that test developers use to test the efficiency of items [24]. The discrimination of an item can be measured comparing the number of individuals have upper point, answering correctly an item with the number of individuals lower points, answering correctly an item. If there is any discrimination between people with upper and lower points, it means that more people in upper level will be answering correctly any item than that of in lower level [25].

2.2.6. Computing the Reliability of the Inventory
It donates reliability that to determine if the responses given for the scenarios produce the consistent measures. Item total correlation for each scenario, and Cronbach alpha coefficient of all the inventory were calculated testing the reliability of inventory.

\section{Findings}

This section involves the findings revealed in the development of caring thinking skills inventory based on problem scenarios.

\subsection{The Results of Content Validity about Appropriateness of Scenarios - Attainments}

The results of content validity performed to determine if each problem scenarios are suitable to attainments constructed are as follows:

Table 6. The results of content validity about appropriateness of scenarios - attainments

\begin{tabular}{|c|c|c|c|c|c|}
\hline Scenario & Criteria & Mean & Scenario & Criteria & Mean \\
\hline \multirow{2}{*}{1} & Compatibility & 4.2 & 11 & Compatibility & 4.8 \\
\hline & Intelligibility & 4.6 & & Intelligibility & 4.4 \\
\hline \multirow{2}{*}{2} & Compatibility & 4.6 & 12 & Compatibility & 5.0 \\
\hline & Intelligibility & 3.8 & & Intelligibility & 4.4 \\
\hline \multirow{2}{*}{3} & Compatibility & 4.8 & 13 & Compatibility & 3.8 \\
\hline & Intelligibility & 4.6 & & Intelligibility & 4.2 \\
\hline \multirow{2}{*}{4} & Compatibility & 4.0 & 14 & Compatibility & 3.6 \\
\hline & Intelligibility & 3.6 & & Intelligibility & 4.2 \\
\hline \multirow{2}{*}{5} & Compatibility & 4.6 & 15 & Compatibility & 3.8 \\
\hline & Intelligibility & 3.6 & & Intelligibility & 4.4 \\
\hline \multirow{2}{*}{6} & Compatibility & 4.4 & 16 & Compatibility & 4.4 \\
\hline & Intelligibility & 4.4 & & Intelligibility & 4.4 \\
\hline \multirow{2}{*}{7} & Compatibility & 4.6 & 17 & Compatibility & 4.0 \\
\hline & Intelligibility & 4.4 & & Intelligibility & 4.4 \\
\hline \multirow{2}{*}{8} & Compatibility & 4.8 & 18 & Compatibility & 4.2 \\
\hline & Intelligibility & 4.8 & & Intelligibility & 4.4 \\
\hline \multirow{2}{*}{9} & Compatibility & 3.8 & 19 & Compatibility & 4.6 \\
\hline & Intelligibility & 4.0 & & Intelligibility & 4.4 \\
\hline \multirow{2}{*}{10} & Compatibility & 5.0 & 20 & Compatibility & 4.6 \\
\hline & Intelligibility & 5.0 & & Intelligibility & 4.6 \\
\hline
\end{tabular}

It is seen that the arithmetic average of evaluation points from five experts in study of content validity changes from 3.8 to 5.0 as for the rules of Turkish grammar, and intelligibility, the arithmetic average of scenarios ranges from 3.6 to 5.0. The results show that scenarios conform to the attainments, and they have high intelligibility.

\subsection{The Findings of the Responses of Students for Constructing Items of Scenarios}

The responses of students have been analyzed to write the items of scenarios of caring thinking skills. As explained previously, two possibilities regarding how the hero in the incident will behave in the last of scenario that students read have been presented. Based on the theory, first possibility was composed as a constructed option, which represents an insensitive/ apathetical thinking or behavior that reflects the lowest level in the taxonomy. So, when students select this option, they will not come up with an idea, or response. A part of students was directed at first possibility while the remaining part expressed their interpretations about how the hero will do in the story as a second way. 
Table 7. The number of students selecting the first possibility by scenarios

\begin{tabular}{|c|c|c|}
\hline Possibility one & Participants & Number \\
\hline Teacher Emrah would go back owing to the bad conditions & $\begin{array}{l}\text { s1, s7, s9, s13, s14, s15, s16, s17, s25, s36, s37, s42, s43, s45, } \\
\text { s47, s48 }\end{array}$ & 16 \\
\hline The teacher Emrah would think as Salih do, too & $\begin{array}{l}\text { s1, s3, s6, s7, s8, s9, s10, s11, s14, s16, s17, s18, s19, s27, s31, } \\
\mathrm{s} 33, \mathrm{~s} 35, \mathrm{~s} 36, \mathrm{~s} 37, \mathrm{~s} 38, \mathrm{~s} 42, \mathrm{~s} 43, \mathrm{~s} 45, \mathrm{~s} 50, \mathrm{~s} 51\end{array}$ & 25 \\
\hline $\begin{array}{l}\text { The teacher Emrah thinks this condition of the school will be } \\
\text { improved. }\end{array}$ & $\begin{array}{l}\text { s1, s7, s15, s16, s17, s20, s25, s36, s37, s39, s40, s43, s46, s48, } \\
\text { s50, s53 }\end{array}$ & 16 \\
\hline $\begin{array}{l}\text { Salih ignores his friends 'experiences under this hard } \\
\text { condition. }\end{array}$ & $\begin{array}{l}\text { s1, s7, s14, s15, s16, s17, s25, s33, s35, s36, s39, s40, s41, s42, } \\
\text { s45, s48, s52, s53, s54 }\end{array}$ & 19 \\
\hline $\begin{array}{l}\text { The teacher Emrah would wait the man of the village sitting } \\
\text { despairingly }\end{array}$ & $\begin{array}{l}\mathrm{s} 1, \mathrm{~s} 3, \mathrm{~s} 5, \mathrm{~s} 7, \mathrm{~s} 8, \mathrm{~s} 9, \mathrm{~s} 14, \mathrm{~s} 16, \mathrm{~s} 17, \mathrm{~s} 18, \mathrm{~s} 19, \mathrm{~s} 25, \mathrm{~s} 33, \mathrm{~s} 34, \mathrm{~s} 35, \\
\mathrm{~s} 36, \mathrm{~s} 37, \mathrm{~s} 38, \mathrm{~s} 39, \mathrm{~s} 40, \mathrm{~s} 41, \mathrm{~s} 42, \mathrm{~s} 43, \mathrm{~s} 45, \mathrm{~s} 49, \mathrm{~s} 50, \mathrm{~s} 51, \mathrm{~s} 52, \\
\mathrm{~s} 53, \mathrm{~s} 54\end{array}$ & 30 \\
\hline $\begin{array}{l}\text { Salih would go other friend ignoring the condition that Yusuf } \\
\text { was crying }\end{array}$ & $\begin{array}{l}\text { s1, s7, s13, s16, s17, s25, s35, s36, s38, s42, s43, s46, s48, s50, } \\
\text { s51, s53 }\end{array}$ & 16 \\
\hline Salih gives no importance on Yusuf's dreams & $\mathrm{s} 1, \mathrm{~s} 7, \mathrm{~s} 13, \mathrm{~s} 16, \mathrm{~s} 17, \mathrm{~s} 25, \mathrm{~s} 35, \mathrm{~s} 36, \mathrm{~s} 39, \mathrm{~s} 42, \mathrm{~s} 48, \mathrm{~s} 51$ & 12 \\
\hline The teacher Emrah is different to this situation. & $\mathrm{s} 1, \mathrm{~s} 7, \mathrm{~s} 9, \mathrm{~s} 13, \mathrm{~s} 16, \mathrm{~s} 17, \mathrm{~s} 18, \mathrm{~s} 19, \mathrm{~s} 21, \mathrm{~s} 25, \mathrm{~s} 35, \mathrm{~s} 36, \mathrm{~s} 37$ & 13 \\
\hline The teacher Emrah would strike back Yusuf's dad. & $\begin{array}{l}\text { s1, s6, s7, s9, s13, s14, s15, s16, s17, s21, s25, s27, s33, s35, s36, } \\
\text { s42, s43, s49, s51 }\end{array}$ & 19 \\
\hline $\begin{array}{l}\text { After his father left Yusuf to the school, he would go back the } \\
\text { home no saying anything to the teacher. }\end{array}$ & $\begin{array}{l}\text { s1, s7, s9, s11, s16, s17, s21, s24, s25, s27, s35, s36, s37, s38, } \\
\mathrm{s} 41, \mathrm{~s} 42, \mathrm{~s} 45, \mathrm{~s} 48, \mathrm{~s} 51, \mathrm{~s} 53\end{array}$ & 20 \\
\hline $\begin{array}{l}\text { Salih would not aware of no learning Yusuf multiplication } \\
\text { table. }\end{array}$ & $\begin{array}{l}\text { s1, s7, s8, s9, s12, s13, s15, s16, s17, s18, s21, s25, s27, s31, s35, } \\
\mathrm{s} 36, \mathrm{~s} 38, \mathrm{~s} 40, \mathrm{~s} 41, \mathrm{~s} 42, \mathrm{~s} 43, \mathrm{~s} 45, \mathrm{~s} 48, \mathrm{~s} 51\end{array}$ & 24 \\
\hline Salih would perform both Yusuf and Hasan' tasks. & $\begin{array}{l}\text { s1, s2, s3, s5, s6, s7, s8, s10, s11, s12, s13, s14, s15, s16, s17, } \\
\text { s19, s21, s25, s33, s34, s35, s36, s37, s38, s39, s40, s41, s42, } \\
\text { s43, s45, s47, s49, s51, s54 }\end{array}$ & 34 \\
\hline Hasan would no longer want to draw a picture. & $\begin{array}{l}\mathrm{s} 1, \mathrm{~s} 6, \mathrm{~s} 7, \mathrm{~s} 8, \mathrm{~s} 9, \mathrm{~s} 11, \mathrm{~s} 12, \mathrm{~s} 13, \mathrm{~s} 14, \mathrm{~s} 15, \mathrm{~s} 16, \mathrm{~s} 17, \mathrm{~s} 18, \mathrm{~s} 19, \mathrm{~s} 20, \\
\mathrm{~s} 21, \mathrm{~s} 25, \mathrm{~s} 34, \mathrm{~s} 35, \mathrm{~s} 36, \mathrm{~s} 37, \mathrm{~s} 38, \mathrm{~s} 39, \mathrm{~s} 40, \mathrm{~s} 41, \mathrm{~s} 42, \mathrm{~s} 43, \mathrm{~s} 44, \\
\mathrm{~s} 45, \mathrm{~s} 47, \mathrm{~s} 48, \mathrm{~s} 49, \mathrm{~s} 50, \mathrm{~s} 51, \mathrm{~s} 52, \mathrm{~s} 54\end{array}$ & 36 \\
\hline Yusuf thinks Hasan's thoughts really are not important & $\begin{array}{l}\text { s1, s4, s6, s7, s12, s13, s15, s16, s17, s18, s20, s21, s23, s25, s28, } \\
\text { s33, s35, s36, s37, s38, s40, s41, s42, s43, s46, s47,s49, s50, s51, } \\
\text { s54 }\end{array}$ & 30 \\
\hline Yusuf doesn't aware of importance on dogs for Hasan. & $\begin{array}{l}\mathrm{s} 1, \mathrm{~s} 5, \mathrm{~s} 7, \mathrm{~s} 8, \mathrm{~s} 11, \mathrm{~s} 12, \mathrm{~s} 13, \mathrm{~s} 14, \mathrm{~s} 15, \mathrm{~s} 16, \mathrm{~s} 17, \mathrm{~s} 18, \mathrm{~s} 19, \mathrm{~s} 20, \mathrm{~s} 21, \\
\mathrm{~s} 23, \mathrm{~s} 25, \mathrm{~s} 28, \mathrm{~s} 29, \mathrm{~s} 33, \mathrm{~s} 35, \mathrm{~s} 36, \mathrm{~s} 37, \mathrm{~s} 38, \mathrm{~s} 39, \mathrm{~s} 41, \mathrm{~s} 42, \mathrm{~s} 47, \\
\mathrm{~s} 48, \mathrm{~s} 49, \mathrm{~s} 50, \mathrm{~s} 51, \mathrm{~s} 52\end{array}$ & 33 \\
\hline $\begin{array}{l}\text { Salih doesn't pay attention to their discussion of Hasan and } \\
\text { Yusuf. }\end{array}$ & $\begin{array}{l}\text { s1, s4, s7, s8, s9, s10, s11, s12, s14, s15, s17, s21, s22, s23, s25, } \\
\text { s27, s35, s36, s37, s38, s39, s41, s42, s43, s49, s51, s53 }\end{array}$ & 27 \\
\hline $\begin{array}{l}\text { Yusuf and Hasan will not have a feeling regarding children in } \\
\text { other nations could not go to the school. }\end{array}$ & $\begin{array}{l}\text { s1, s3, s4, s6, s7, s8, s9, s10, s11, s12, s15, s16, s17, s19, s21, } \\
\text { s22, s23, s25, s33, s35, s36, s37, s39, s41, s42, s43, s44, s45, } \\
\text { s48, s49, s51, s53 }\end{array}$ & 33 \\
\hline $\begin{array}{l}\text { Hasan and Yusuf would not consider advices that teacher said } \\
\text { for them }\end{array}$ & $\begin{array}{l}\mathrm{s} 1, \mathrm{~s} 6, \mathrm{~s} 7, \mathrm{~s} 8, \mathrm{~s} 12, \mathrm{~s} 13, \mathrm{~s} 14, \mathrm{~s} 15, \mathrm{~s} 7, \mathrm{~s} 19, \mathrm{~s} 21, \mathrm{~s} 22, \mathrm{~s} 23, \mathrm{~s} 25, \mathrm{~s} 29, \\
\mathrm{~s} 35, \mathrm{~s} 36, \mathrm{~s} 37, \mathrm{~s} 38, \mathrm{~s} 39, \mathrm{~s} 40, \mathrm{~s} 41, \mathrm{~s} 42, \mathrm{~s} 47, \mathrm{~s} 49, \mathrm{~s} 50, \mathrm{~s} 51\end{array}$ & 27 \\
\hline It would not be positive changes in their relations. & $\begin{array}{l}\text { s1, s4, s6, s7, s8, s9, s10, s11, s12, s13, s15, s17, s18, s21, s22, } \\
\mathrm{s} 23, \mathrm{~s} 25, \mathrm{~s} 29, \mathrm{~s} 33, \mathrm{~s} 35, \mathrm{~s} 36, \mathrm{~s} 37\end{array}$ & 22 \\
\hline Students would ignore exertions teacher gave for themselves. & $\begin{array}{l}\text { s1, s4, s6, s7,s8, s9, s10, s11, s12, s13, s14, s15, s16, s17, s19, } \\
\text { s21, s22, s23, s25, s29, s33, s35, s36, s37, s42, s43, s47, s48, } \\
\text { s49, s50, s51 }\end{array}$ & 31 \\
\hline
\end{tabular}

Table 8. The coding of students' opinions in Scenario 1 regularly into stages of normative thinking

\begin{tabular}{|l|l|}
\hline $\begin{array}{l}\text { Stage of } \\
\text { response }\end{array}$ & Statements \\
\hline Second stage & $\begin{array}{l}\text { S27. He may have dreamed a spectacular school environment } \\
\text { S44. The teacher, Emrah may have come with different ideals. }\end{array}$ \\
\hline Third stage & $\begin{array}{l}\text { S33. He has come to teach students literacy } \\
\text { S34. Because, my goal is to become a teacher, and provide with a good future. } \\
\text { S23. If I were him, I would gather money to improve the school, also do best one of my capabilities because education is very } \\
\text { important. }\end{array}$ \\
\hline Fourth stage & $\begin{array}{l}\text { S34. He may have come to the village with imagination which conditions are better. If I were him, I would regulate regularly } \\
\text { cooperating with students. Because, my goal is to become a teacher, and provide with a good future. }\end{array}$ \\
\hline Fifth stage & $\begin{array}{l}\text { S21. Incase children remain educated, I would call Ankara, and wanted to meet the needs of desks, tables, schools. } \\
\text { S22. I would talk with the headman of the village, I said him that the school must be repaired, and maintained, I would help it. } \\
\text { Since every child has the right of read, and help it to the happiness and education of new generation. } \\
\text { S51. I would give teaching students there taking many employees to the village, and improving worn out school in order to } \\
\text { choose a good job when they are grown. }\end{array}$ \\
\hline
\end{tabular}

In 'Possibility 1' given as a constructed option, it is aimed to reveal the situation that students can think uncaringly in 
case of they read in the scenarios or conditions. Although they tend to choose the possibility one owing to some students avoid of stating their opinions, or they have a will to choose easy one, we revealed that they marked this option consciously. It was benefited from the responses given for 'Possibility two' to write the items of scenarios. As the theoretical bases of caring thinking are stated, the behavior patterns of caring thinking were scrutinized beside uncaring behavior. The items of scenarios were written by these stages. These items were obtained through the coding of students' responses into taxonomical stages properly. The interpretations students made on each scenario in the inventory were presented in Table 8 .

As it was mentioned above, the responses of students on scenarios were obtained and classified by the stages of Krathwohl's taxonomy. Then, the statements appropriate for the context of story flow, and scenario logic were chosen, as are demonstrated itallically in Table 8.

\subsection{The Findings about Face Validity to Assess Appropriateness of Scenarios Items - Criteria}

For the face validity, we asked three experts to assess the compatibility of 100 items in 20 problem scenarios, and criteria or descriptors for the stages of caring thinking. The results of their assessments are as follows.

Table 9. The results of face validity regarding the appropriateness of items - criteria

\begin{tabular}{|c|c|c|c|c|c|c|c|c|c|c|c|}
\hline \multirow{6}{*}{ Scenario 1} & St. & $\mathrm{X}$ & \multirow{6}{*}{ Scenario 6} & St. & $\mathrm{X}$ & \multirow{6}{*}{ Scenario 11} & St & $\mathrm{X}$ & \multirow{6}{*}{ Scenario 16} & St. & $X$ \\
\hline & 1 & 4.0 & & 1 & 5.0 & & 1 & 4.7 & & 1 & 5.0 \\
\hline & 2 & 4.1 & & 2 & 5.0 & & 2 & 5.0 & & 2 & 4.7 \\
\hline & 3 & 4.0 & & 3 & 5.0 & & 3 & 4.7 & & 3 & 4.7 \\
\hline & 4 & 4.0 & & 4 & 4.0 & & 4 & 5.0 & & 4 & 4.7 \\
\hline & 5 & 5.0 & & 5 & 5.0 & & 5 & 5.0 & & 5 & 5.0 \\
\hline \multirow{6}{*}{ Scenario 2} & $\mathrm{St}$ & $\mathrm{X}$ & \multirow{6}{*}{ Scenario 7} & $\mathrm{St}$ & $\mathrm{X}$ & \multirow{6}{*}{ Scenario 12} & $\mathrm{St}$ & $\mathrm{X}$ & \multirow{6}{*}{ Scenario 17} & $\mathrm{St}$ & $X$ \\
\hline & 1 & 2.0 & & 1 & 3.0 & & 1 & 5.0 & & 1 & 3.6 \\
\hline & 2 & 4.1 & & 2 & 5.0 & & 2 & 4.3 & & 2 & 5.0 \\
\hline & 3 & 4.0 & & 3 & 4.0 & & 3 & 4.7 & & 3 & 4.0 \\
\hline & 4 & 4.8 & & 4 & 3.3 & & 4 & 3.3 & & 4 & 4.3 \\
\hline & 5 & 4.1 & & 5 & 4.3 & & 5 & 5.0 & & 5 & 5.0 \\
\hline \multirow{6}{*}{ Scenario 3} & $\mathrm{St}$ & $\mathrm{X}$ & \multirow{6}{*}{ Scenario 8} & $\mathrm{St}$ & $\mathrm{X}$ & \multirow{6}{*}{ Scenario 13} & $\mathrm{St}$ & $\mathrm{X}$ & \multirow{6}{*}{ Scenario 18} & $\mathrm{St}$ & $\mathrm{X}$ \\
\hline & 1 & 3,7 & & 1 & 4.7 & & 1 & 4.0 & & 1 & 5.0 \\
\hline & 2 & 4.0 & & 2 & 5.0 & & 2 & 4.7 & & 2 & 5.0 \\
\hline & 3 & 3,7 & & 3 & 5.0 & & 3 & 3.0 & & 3 & 3.6 \\
\hline & 4 & 5.0 & & 4 & 5.0 & & 4 & 3.3 & & 4 & 4.7 \\
\hline & 5 & 5.0 & & 5 & 5.0 & & 5 & 5.0 & & 5 & 4.0 \\
\hline \multirow{6}{*}{ Scenario 4} & St & $\mathrm{X}$ & \multirow{6}{*}{ Scenario 9} & $\mathrm{St}$ & $\mathrm{X}$ & \multirow{6}{*}{ Scenario 14} & $\mathrm{St}$ & $\mathrm{X}$ & \multirow{6}{*}{ Scenario 19} & St & $\mathrm{X}$ \\
\hline & 1 & 4.3 & & 1 & 4.7 & & 1 & 4.7 & & 1 & 4.3 \\
\hline & 2 & 5.0 & & 2 & 4.7 & & 2 & 5.0 & & 2 & 5.0 \\
\hline & 3 & 4.0 & & 3 & 3.0 & & 3 & 4.3 & & 3 & 5.0 \\
\hline & 4 & 4.3 & & 4 & 4.3 & & 4 & 5.0 & & 4 & 5.0 \\
\hline & 5 & 5.0 & & 5 & 4.6 & & 5 & 5.0 & & 5 & 5.0 \\
\hline \multirow{6}{*}{ Scenario 5} & St & $\mathrm{X}$ & \multirow{6}{*}{ Scenario 10} & $\mathrm{St}$ & $\mathrm{X}$ & \multirow{6}{*}{ Scenario 15} & St & $\mathrm{X}$ & \multirow{6}{*}{ Scenario 20} & St & $\mathrm{X}$ \\
\hline & 1 & 5.0 & & 1 & 4.7 & & 1 & 5.0 & & 1 & 4.0 \\
\hline & 2 & 3.6 & & 2 & 5.0 & & 2 & 5.0 & & 2 & 4.7 \\
\hline & 3 & 4.8 & & 3 & 4.7 & & 3 & 5.0 & & 3 & 5.0 \\
\hline & 4 & 1.7 & & 4 & 5.0 & & 4 & 5.0 & & 4 & 4.7 \\
\hline & 5 & 5.0 & & 5 & 5.0 & & 5 & 3.6 & & 5 & 4.0 \\
\hline
\end{tabular}

They assessed the compatibility of items - criteria with a grading system changing from 1 to 5 points. As it is seen in Table 9, all the items written in the scenarios numbered as $1,3,4,6,7,8,9,10,11,12,13,14,15,16,17,18,19$, and 20 have an acceptable level for the compatibility. Also, some items in the Scenario 2, and 5 have an arithmetic mean below acceptable degree. But, these items were corrected in way that meet the criteria given according to the suggestions of the experts put forward. 


\subsection{The Findings of Structure Validation of Inventory of Caring Thinking Skills}

The independent $t$ test was performed to calculate item discrimination indices for lower \%27- upper \%27 groups, which is one of validation types of structure. The results of independent groups $\mathrm{t}$ test are presented in Table 10.

Table 10. The Results of Independent Groups t Tests for the Lower - Upper $\% 27$ Groups Item Discrimination İndices

\begin{tabular}{|c|c|c|c|c|c|c|c|}
\hline Scenario & Group & $\mathrm{N}$ & $\mathrm{X}$ & SD & $\mathrm{df}$ & $\mathrm{t}$ & $\mathrm{p}$ \\
\hline \multirow{2}{*}{1} & Lower & 50 & 3,66 & 1,153 & 79,469 & $-3,299$ & ,001 \\
\hline & Upper & 49 & 4,29 & ,677 & & & \\
\hline \multirow{2}{*}{2} & Lower & 50 & 3,98 & 1,377 & 60,717 & $-4,363$ &, 000 \\
\hline & Upper & 50 & 4,88 & ,479 & & & \\
\hline \multirow{2}{*}{3} & Lower & 50 & 3,46 & 1,216 & 98 & $-2,631$ &, 010 \\
\hline & Upper & 50 & 4,08 & 1,140 & & & \\
\hline \multirow{2}{*}{4} & Lower & 50 & 3,84 & ,976 & 69,203 & $-5,780$ & ,000 \\
\hline & Upper & 50 & 4,72 &, 454 & & & \\
\hline \multirow{2}{*}{5} & Lower & 50 & 3,48 & 1,297 & 88,804 & $-4,785$ &, 000 \\
\hline & Upper & 50 & 4,56 & ,929 & & & \\
\hline \multirow{2}{*}{6} & Lower & 50 & 3,26 & 1,411 & 76,351 & $-4,912$ &, 000 \\
\hline & Upper & 50 & 4,38 & ,779 & & & \\
\hline \multirow{2}{*}{7} & Lower & 50 & 2,90 & 1,418 & 98 & $-5,299$ &, 000 \\
\hline & Upper & 50 & 4,30 & 1,216 & & & \\
\hline \multirow{2}{*}{8} & Lower & 50 & 4,10 & 1,165 & 51,827 & $-5,146$ &, 000 \\
\hline & Upper & 50 & 4,96 & ,198 & & & \\
\hline \multirow{2}{*}{9} & Lower & 50 & 2,74 & 1,306 & 98 & $-6,032$ &, 000 \\
\hline & Upper & 50 & 4,28 & 1,246 & & & \\
\hline \multirow{2}{*}{10} & Lower & 50 & 3,28 & 1,443 & 69,915 & $-6,199$ &, 000 \\
\hline & Upper & 50 & 4,68 & ,683 & & & \\
\hline \multirow[t]{2}{*}{11} & Lower & 50 & 3,80 & 1,195 & 86,117 & $-6,199$ &, 000 \\
\hline & Upper & 50 & 4,72 &, 809 & & & \\
\hline \multirow[t]{2}{*}{12} & Lower & 50 & 3,30 & 1,529 & 68,677 & $-6,309$ &, 000 \\
\hline & Upper & 50 & 4,80 & ,699 & & & \\
\hline \multirow{2}{*}{13} & Lower & 50 & 3,52 & 1,359 & 58,210 & $-6,266$ &, 000 \\
\hline & Upper & 50 & 4,78 &, 418 & & & \\
\hline \multirow{2}{*}{14} & Lower & 50 & 2,90 & 1,093 & 98 & $-7,999$ &, 000 \\
\hline & Upper & 50 & 4,44 & ,812 & & & \\
\hline \multirow{2}{*}{15} & Lower & 50 & 3,60 & 1,471 & 62,926 & $-5,481$ & ,000 \\
\hline & Upper & 50 & 4,82 &, 560 & & & \\
\hline \multirow{2}{*}{16} & Lower & 50 & 3,50 & 1,446 & 73,233 & $-5,478$ & ,000 \\
\hline & Upper & 50 & 4,76 & ,744 & & & \\
\hline \multirow{2}{*}{17} & Lower & 50 & 2,70 & 1,147 & 98 & $-3,726$ & 000 \\
\hline & Upper & 50 & 3,58 & 1,213 & & & \\
\hline \multirow{2}{*}{18} & Lower & 50 & 3,70 & 1,460 & 85,598 & $-2,494$ & ,015 \\
\hline & Upper & 50 & 4,32 & ,978 & & & \\
\hline \multirow{2}{*}{19} & Lower & 49 & 3,041 & 1,224 & 97 & $-5,133$ & ,000 \\
\hline & Upper & 50 & 4,24 & 1,098 & & & \\
\hline \multirow{2}{*}{20} & Lower & 50 & 3,28 & 1,195 & 77,005 & $-4,746$ & ,000 \\
\hline & Upper & 50 & 4,20 & ,670 & & & \\
\hline
\end{tabular}

In order to determine the discrimination indices of items for each scenario in the inventory, $t$ value of the difference of arithmetic averages of lower - upper \%27 groups were calculated. As a result of independent t test for two sample, it is seen that $t$ values differ in significantly for each scenario $(\mathrm{p}<.05)$. This finding indicates that the items in each scenario and scenarios are discriminatory to measure caring thinking skills. Based on this finding, it is say to possible that the inventory can discriminate between the individual who thinks caringly and uncaringly. 


\subsection{The Findings of the Reliability of the Inventory of Caring Thinking Skills}

In order to calculate the reliability of the inventory of caring thinking skills, internal consistency was scrutinized.

Table 11. Results of Inner Consistency Coefficients of Reliability of Caring Thinking Skills Inventory

\begin{tabular}{|c|c|c|c|}
\hline Scenario & $\mathrm{r}$ & Scenario & $\mathrm{r}$ \\
\hline 1 &, 098 & 11 &, 283 \\
\hline 2 &, 238 & 12 &, 282 \\
\hline 3 &, 121 & 13 &, 284 \\
\hline 4 &, 238 & 14 &, 377 \\
\hline 5 &, 263 & 15 &, 310 \\
\hline 6 &, 235 & 16 &, 308 \\
\hline 7 &, 346 & 17 &, 078 \\
\hline 8 &, 364 & 18 &, 140 \\
\hline 9 &, 277 & 19 &, 257 \\
\hline 10 &, 286 & 20 &, 235 \\
\hline \multirow{2}{*}{ Total } & $\mathrm{n}$ & $\mathrm{r}$ & \\
\cline { 2 - 5 } & 20 &, 673 & \\
\hline
\end{tabular}

The results of reliability show that the degree of item total correlation or internal consistency is above .20 in Table 9. However, it has seen that item total correlation coefficient of only two scenarios are below .10. Besides, Cronbach alpha coefficient of the inventory of caring thinking skills is calculated as .673.

\section{Conclusions, Discussion \& Recommendations}

The inventory designed and developed to understand if caring thinking is a measurable and improvable skill is valid, and reliable data collection instrument as a result of respectively, qualitative and quantitative studies performed. It is seen that the degree of the compatibility of scenario attainment is extremely good based on content validity. Then, the students' responses about scenarios were corrected, and made it comprehensible, and the data were classified into proper steps, or stages. For the face validity performed to understand to the degree what each statement is suitable to the stages of affective domain taxonomy of Krahtwohl, Bloom \& Masia [11], the experts' assessments indicate that they meet greatly criteria foreseen, but items in some scenarios are not suitable for them sufficiently. So, necessary suggestions from the experts were considered, and regulated. The revisited version of the inventory was applied to students, and the inventory is a discriminative characteristic that the individual thinks caringly and uncaringly as a result of lower $\% 27$ - upper $\% 27$ group analysis. It was reached evidence that it is a reliable instrument as calculated to be .672. Since the caring thinking skills inventory, including 20 scenarios in booklet format takes one hour to complete it, the reliability coefficient of it is .70 below. The reliability value of Cornell Critical Thinking Test which is similar to our inventory also is .62. It has been said that it gives reliable results, which is extremely acceptable, and used in many studies as a universal criterion [12]. The problem scenarios in the inventory consist of 20 connected, sequential events. The hero has five ways to choose in the scenarios. They are asked to answer the question 'which ways would they choose if students were the hero'. Therefore, the caring thinking skills inventory accounts for 20 problem scenarios, which have 5 options, and 100 items. The lowest point is 20 , and the highest point is 100 . To be answered is quietly easy. The degree to what students think caringly can be measured using an answer key which rating of items ranges from 1 to 5 in each scenario. Although advantages such as the caring thinking skills inventory is a multiple choice test, based on the story, and is easy to calculate, it can be regard as a disadvantage the fact that it takes long time decreases its usability. The usage span of the inventory is approximately 40-50 minutes.

Finally, the following the types of content and face validation, it has been seen that each scenario has any discriminating characteristic by means of lower \%27 upper $\% 27$ discrimination analysis in the pilot study. It shows that each scenario measures really the construct desired. The value found in the results of reliability analysis demonstrated the similarity of coefficient revealed from some measurement instruments (for example, Cornell Critical Thinking Test) in the literature. Thereby, it is possible to say that the inventory validated is reliable.

The inventory is a part of the process of a curriculum development based on affect in the context of Turkey. Although the process of constructing scenarios depends on objectives which were specified, and derived from students' needs in this context, these objectives reflect potential experiences occurring in a daily life in any country or community. The scope of use in global sense is quite wide. It is a data collection instrument to be applied on students of which they range from middle school to university in different cultures, and contexts. As Sharp stated, caring thinking reinforces students to establish a sound value system, from which to make sound and compassionate judgments. It also directs at moral and aesthetic perceptions. We display affective states such as prizing, esteeming, cherishing, healing, consoling, taking care of, nurturing, empathizing, sympathizing, valuing, appreciating, celebrating, and responding to the other in caring thinking. Caring thinking arises from our perceptual, sensual and emotional lives and determines for how we behave in an event. In this respect, it is an inevitable skill for human life, and it should be involved in curriculum [7].

In consideration of knowledge mentioned previously, caring thinking is limited as a research subject although it is not a new concept. A way to incorporate caring thinking into teaching process is to connect with more theoretical 
frameworks, or concepts of human development. It has been thought that caring thinking should be included to curricula to establish relationships with these concepts. Making these connections can produce ideas regarding where, how, which situation, when the inventory can be used. One of the concepts implied is character, and character education. Bialik, Bogan, Fadel \& Horvathova uncovered six qualities and associated concepts of human character. (1) Mindfulness (Wisdom, self-awareness, self-management self-actualization, observation etc.); (2) Curiosity (Open-mindedness, exploration, passion, self-direction, motivation, initiative, innovation etc.); (3) Courage (Bravery, determination, fortitude, confidence, risk taking, persistence, toughness etc.); (4) Resilience (Perseverance, grit, tenacity, resourcefulness, spunk, self-discipline, effort, diligence etc.); (5) Ethics (Benevolence, humaneness, integrity, respect, justice, equity, fairness, kindness, altruism etc.); (6) Leadership (Responsibility, abnegation, accountability, dependability, reliability, conscientiousness etc.) [26]. It can be said that these qualities are associated with characteristics of caring thinkers. Helping individuals increase caring thinking skills contributes to the character development. In this respect, students' performances (affective behavior dispositions, caring thinking skills etc.) can be measured in educational projects to conduct in the context of character education. So that, the changes in students' development through curriculum delivered can be understood. Similarly, as Sharp said, it can be addressed in moral and values education since caring thinking is the skill which provides with a sound, values system helping to students makes sound, passionate judgments. Either a value or a belief necessarily rests on assumptions and actions of all the dimensions of caring thinking. No matter which method you choose, whether it is qualitative one (action research, case study, phenomenology etc.) or whether it is quantitative one (survey, experimental design etc.), values education studies can be conducted suitable to value components underling in the inventory. For this, you read carefully the content of scenarios, and attainments based on them. Caring thinking is a related skill with moral structures. Because, recognizing a problem as moral one is a judgment; defining a moral problem is an issue of caring thinking [7]. From this standpoint, caring thinker deals with a problem considering moral norms, principles, and values, and acts it. Caring thinking can be addressed as a part or component of moral education. The usage of this inventory with the research methods expressed above can be just a part of your research. The inventory can be employed in a practical study which aims to transform emotions to thought or behavior in positive direction. For, our emotions help to distinguish what it is significantly moral in a situation. The moral need uncovering in most cases underlies in an emotion as can be described as moral perceptions. Thus, emotions are fundamental drives of thought and judgments. Moral judgments arise from them.

One of the most fundamental factors for teaching of caring thinking is Philosophy for Children (P4C) established by Matthew Lipman. Known as 'thinking skills' program which aims to develop critical, creative, and caring thinking skills [27], P4C helps positively also students' affective development [28]. This philosophical movement is an approach to enable students' skills for inquiry to reach reasonable, judgments regarding questions, and issues that arise in their own experiences. With aim of developing pro-social behaviors, and reducing violence, the focus of a number of $\mathrm{P} 4 \mathrm{C}$ is on caring thinking [29]. $\mathrm{C} 4 \mathrm{P}$ provides with the opportunities for students' rational, creative, and caring thinking by developing their thinking, and social skills in the classroom. Thus, it helps to transform the world to a better place [30]. For him, acquisition of caring thinking can be achieved through philosophical dialog in the community of inquiry [31]. Eventually, the all the discussions reveal that educational projects on $\mathrm{C} 4 \mathrm{P}$ or a research by using the approach to the community of inquiry contribute to acquire students' caring thinking. This inventory can be used as an instrument measuring caring thinking skills in such a study. 


\section{Appendix A}

Appendix A consists of a list of attainments suitable to scenarios of the inventory which were constructed around the types of caring thinking including appreciative thinking, affective thinking, normative thinking, active thinking, and emphatic thinking.

\begin{tabular}{|c|c|c|}
\hline Scenario & The types of caring thinking & Attainments \\
\hline 1 & Normative thinking & Students can regulate self-care ability in daily life using normative thinking skills. \\
\hline 2 & Active thinking & $\begin{array}{l}\text { Students can demonstrate conservative behaviors against animal abuse or nature } \\
\text { harassment that they observed in their environment using active thinking skills. }\end{array}$ \\
\hline 3 & Active thinking & $\begin{array}{l}\text { Students can produce a way of solutions using active thinking skills as to as minimize the } \\
\text { bad conditions of people living at their environments. }\end{array}$ \\
\hline 4 & Affective thinking & Students can employ affective thinking skills to encourage them to reach a given ideal. \\
\hline 5 & Active thinking & Students can think actively in order to perform seriously and caringly the tasks given. \\
\hline 6 & Emphatic thinking & $\begin{array}{l}\text { Students can affect positively emotions of a person whom they saw his/ her sad } \\
\text { appearances employing emphatic thinking skills. }\end{array}$ \\
\hline 7 & Emphatic thinking & $\begin{array}{l}\text { Students can motivate their friends to cheer on a particular target using emphatic thinking } \\
\text { skills. }\end{array}$ \\
\hline 8 & Affective thinking & $\begin{array}{l}\text { Students can show susceptibility to the events regarding the child abuse using affective } \\
\text { thinking skills. }\end{array}$ \\
\hline 9 & Normative thinking & $\begin{array}{l}\text { Students can think one's best moral norms when they feel or experience different } \\
\text { immoral situations using normative thinking skills }\end{array}$ \\
\hline 10 & Appreciative thinking & $\begin{array}{l}\text { Students can think ways to atone a close friend whom they broke his or her heart in daily } \\
\text { life by using appreciative thinking skills. }\end{array}$ \\
\hline 11 & Normative thinking & $\begin{array}{l}\text { Students can find ways to increase the learning degree of their friends with learning } \\
\text { deficiencies to the desired level using normative thinking skills. }\end{array}$ \\
\hline 12 & Normative thinking & $\begin{array}{l}\text { Students can pay attention to abide by cooperation rules with people whom they study in } \\
\text { daily life using normative thinking skills. }\end{array}$ \\
\hline 13 & Affective thinking & $\begin{array}{l}\text { Students can develop an positive attitude toward activities that they like using affective } \\
\text { thinking skills. }\end{array}$ \\
\hline 14 & Appreciative thinking & Students can show respect for different ideas using appreciative thinking skills. \\
\hline 15 & Emphatic thinking & $\begin{array}{l}\text { Students can think emphatically in sanctity or past experiences regarding both self or the } \\
\text { others. }\end{array}$ \\
\hline 16 & Active thinking & $\begin{array}{l}\text { Students can soothe their friends in an environment where a quarrel happens by means of } \\
\text { active thinking skills. }\end{array}$ \\
\hline 17 & Emphatic thinking & $\begin{array}{l}\text { Students can demonstrate their compassion for the children devoid of the school } \\
\text { employing emphatic thinking skills. }\end{array}$ \\
\hline 18 & Appreciative thinking & $\begin{array}{l}\text { Students can appreciate individual's advices that they value in daily life via appreciative } \\
\text { thinking skills. }\end{array}$ \\
\hline 19 & Affective thinking & $\begin{array}{l}\text { Students can display polite behaviors toward the individuals in their world using } \\
\text { affective thinking skills. }\end{array}$ \\
\hline 20 & Appreciative thinking & $\begin{array}{l}\text { Students can think appreciatively in order to demonstrate their own faithfulness someone } \\
\text { who helped to attain an achievement in real world. }\end{array}$ \\
\hline
\end{tabular}




\section{REFERENCES}

[1] L. J. Splitter. On the theme of "Teaching for higher order thinking skills, Critical Thinking Across the Disciplines, Vol. 14, No. 4, 52-65, 1995.

[2] M. Lipman. Thinking in Education, Cambridge University Press, UK, 2003.

[3] M. Lipman. Caring as thinking, Inquiry: Critical Thinking across the Disciplines, Vol. 15, No.1, 1-13. 1995.

[4] F. A. M. Fard, H. A. B. Nasrabadi, M. H. Heidari. Philosophy for children: Capacity evaluation of humorous stories in Masnavi based on "Lipman's views on philosophical thinking components, Educational Research and Reviews, Vol 11, Issue 12, 1154-1160, 2016.

[5] A. Shaari, A. Hamzah. A Comparative Review of Caring Thinking and Its Implications on Teaching and Learning. Malaysian Journal of Learning and Instruction: Vol. 15, No. 1, 83-104, 2018.

[6] M. A. Dombayc1. Teaching of Environmental Ethics: Caring Thinking. Journal of Environmental Protection and Ecology 15, No 3A, 1404-1421, 2014.

[7] A. Sharp. Education of the emotions in the classroom community of inquiry, Gifted Education International, Vol. 22, No. 2, 248-257, 2007.

[8] C-H. Lee \& D. Chung. Young Children's Caring Thinking. Proceedings of the Xxii World Congress of Philosophy, Vol. 27, 45-54, 2008.

[9] MoNE. Primary Thinking Education Teacher Guide Book. The Turkish Ministry of National Education. Ankara, 2011.

[10] J. T. Streib. History and analysis of critical thinking. Unpublished Doctorate Thesis, Memphis State University, USA, 1992.

[11] D.R., Krathwohl, B.S., Bloom, B.B. Masia, Taxonomy of Educational Objectives, the Classification of Educational goals. Handbook II: Affective Domain, David McKay Co., Inc New York, 1964.

[12] C. Akar, İlköğretim öğrencilerinde eleştirel düşünme becerileri, Yayımlanmamış doktora tezi, Gazi Üniversitesi Eğitim Bilimleri Enstitüsü, Ankara, 2007.

[13] F., Mirzaei, F.A., Phang, H. Kashefi. Measuring teachers' reflective thinking skills. Procedia - Social and Behavioral Sciences, Vol. 141, 640-647, 2014.

[14] R. Pennington. Reflective thinking in elementary preservice teacher portfolios: can it be measured and taught? Journal of Educational Research and Practice, Vol. 1, No. 1, 37-49, 2011.

[15] Yi-Chun Hong, Ikseon Choi. Assessing reflective thinking in solving design problems: The development of a questionnaire, British Journal of Educational Technology, Vol. 46, No. 4, 848-863, 2015.

[16] E. Jadallah. The development of a reflective teaching observation instrument, Unpublished Doctorate Thesis, The Ohio State University, USA, 1994.
[17] T. C. Leong. What is caring thinking? Teaching caring thinking: Vision, clarifications, justifications and applications, Eric Lau Raffles Girls' School (Secondary), Retrieved September 10, 2010 from http://conference.nie.edu.sg/paper/Converted\%20Pdf/ab00 553.pdf, 2005.

[18] H. Bacanlı. Dört katlı düşünme modeli. Bilim ve Aklın Aydınlığında Eğitim, Vol. 13, No. 146, 29-36, 2012.

[19] W. A. Edmond, T. D. Kennedy. An Applied Guide to Research Designs: Quantitative, Qualitative, and Mixed Methods (Second edition), Sage, USA, 2017.

[20] S. Hesse-Biber, R. B. Johnson. The Oxford Handbook of Multimethod and Mixed Methods Research Inquiry, Oxford University Press, England, 2010.

[21] S. Dilidüzgün. Çağdaş Türk Yazını: Yazın Eğitimine Atılan Ilk Adım. Yapı kredi Yayınları, Ankara, 1996.

[22] S. Sever. Çocuk ve Edebiyat. Tudem Yayınları, İzmir, 2008.

[23] O, Sangoseni, M. Hellman, C. Hill. Development and validation of a questionnaire to assess the effect of online learning on behaviors, attitudes, and clinical practices of physical therapists in the United States regarding evidenced-based clinical practice, Internet Journal of Allied Health Sciences and Practice, Vol. 11, No. 2, 1-12, 2013.

[24] R. L. Brennan. A generalized upper-lower 1tem discrimination index. Educational and Psychology Measurement, Vol. 32, 289-303, 1972.

[25] S. Matlock-Hetzel. Basic concepts in item and test analysis. Paper presented at the Annual Meeting of the Southwest Educational Research Association, Austin, TX, 1997.

[26] M. Bialik, M. Bogan, C. Fadel, M. Horvathova. Character Education for the 21st Century: What Should Students Learn? Center for Curriculum Redesign, Boston, Massachusetts, 2015.

[27] M. A. Paine. The Pedagogy of Philosophy for Children/Philosophical Enquiry. Master Thesis, Research University of York, 2012.

[28] A. Lancaster-Thomas. How effective is Philosophy for Children in contributing to the affective engagement of pupils in the context of secondary Religious Education? P4C and Religious Education Journal of Philosophy in Schools, Vol. 4, Issue 1, 102-122, 2017.

[29] J. Oyler. Philosophy with Children: The Lipman-Sharp Approach to Philosophy for Children. In: Peters M. (eds) Encyclopedia of Educational Philosophy and Theory. Springer, Singapore, 2016.

[30] M. Lipman. Moral education higher - order thinking and philosophy for children. Early Child Development and Care, Vol. 107, Issue 1, 61-70, 1994.

[31] C. Phillips., S. Café. The Efficacy of the Lipmanian Approach to Teaching Philosophy for Children, Childhood \& Philosophy, Vol. 7, Issue 13, 11-28, 2011.

\footnotetext{
i The study was derived from the doctorate thesis of the first author." the footnote in my manuscript
} 